\title{
Rebuilding a Smart and Sustainable Human Society for the World
}

\author{
Renaud Richard \\ renaud@systeme-change.fr / Consultor independiente/interdependiente \\ del programa Accelerating Change Towards Sustainability
}

Recepción: 19/10/2020 Aceptación: 29/10/2020

\begin{abstract}
A bit under 10 years: That's what it took engineers and project managers to bring some human beings to the Moon in the 60's. That's also the time we have to act and rebuild a smart and sustainable human society for the world, and one good indicator for this is reaching the UN's Sustainable Development Goals by the year 2030. The Sulitest's matrix gives an excellent structure to explain the current situation and share information in a structured and helpful way; a way in which all can find an answer to this key question: "What can YOU do NOW to rebuild a smart and sustainable society for the world?" The Framework for Strategic Sustainable Development, also known as The Natural Step Framework, is the best approach I've found to help create needed systemic and strategic changes. Examples from the business or scientific areas can shed light on how to achieve this incredibly needed change to discuss the role of technology, and to explore how systems change and can be transformed. In this paper, I'll share some of the experience and learnings I've gained over the last 20 years, trying to accelerate change towards sustainability. I'll share the fact that it's fun and motivating, as well as an incredible opportunity for all, even if it's not necessarily always easy like most good things which do require efforts to reach. And for all the ones who won't be able to read further: If not now, when? If not here, where? If not you and I, who?
\end{abstract}

KEYWORDS: change / sustainability / human society / biosphere / systems thinking / individual roles / Sulitest / Ray Anderson / FSSD / SDG 


\section{Reconstruyendo una sociedad humana, inteligente y sostenible para el mundo}

Resumen. Algo menos de diez años. Eso es lo que tardaron los ingenieros y los gestores de proyectos en llevar a algunos seres humanos a la Luna en los años sesenta. Ese es también el tiempo que tenemos para actuar y reconstruir una sociedad humana inteligente y sostenible para el mundo, y un buen indicador para ello es alcanzar los objetivos de desarrollo sostenible de la ONU el 2030. La matriz de Sulitest ofrece una excelente estructura para explicar la situación actual y compartir información de forma estructurada y útil. Una forma en la que todos pueden encontrar una respuesta a esta pregunta clave: “Qué puede hacer USTED AHORA para reconstruir una sociedad inteligente y sostenible para el mundo?”. El Marco para el Desarrollo Estratégico Sostenible, también conocido como Marco del Paso Natural, es el mejor enfoque que he conocido para ayudar a crear los cambios sistémicos y estratégicos necesarios. Los ejemplos del ámbito empresarial o científico pueden arrojar luz sobre cómo lograr este cambio increíblemente necesario para discutir el papel de la tecnología, para explorar cómo los sistemas cambian y pueden ser transformados. En este artículo compartiré algunas de las experiencias y aprendizajes que he adquirido en los últimos veinte años, tratando de acelerar el cambio hacia la sostenibilidad. Compartiré que es divertido, motivador y una oportunidad increíble para todos, aunque no siempre sea fácil, como la mayoría de las cosas buenas que requieren esfuerzos para alcanzarlas. Y para todos los que no podrán seguir leyendo: si no es ahora, ¿cuándo? Si no es aquí, ¿dónde? Si no somos tú y yo, ¿quién?

PALABRAS CLAVE: cambio / sostenibilidad / sociedad humana / biósfera / pensamiento de sistemas / roles individuales / Sulitest / Ray Anderson / FSSD / SDG 


\section{INTRODUCTION}

I owe you a warning first: This is not an academic paper, and the format or tone might be unusual to you or not... This is a paper I prepared specifically for the CIIS 2020 conference on "Building a Smart World for Sustainability." I have been invited to give a keynote session to share what I have learnt and practiced over the last 20 years-sometimes in academic settings but most of the time with companies, local communities, NGOs and many kinds of systems.

Since the turn of the millennium, I have been trying to accelerate change towards sustainability and that is what I would like to share with you in this paper: What I learnt from working voluntarily with local groups as a project officer for international NGOs, and as a consultant or facilitator mainly for companies and sometimes for local governments.

This is not an academic paper, but I do wish it to be rigorous and useful: to have some impact. This is what motivated this paper's title: "Rebuilding a Smart and Sustainable Human Society for the World."

In the Methodology section, I'll share the plan with you; how we're going to explore this subject, with what mindset.

The Results section will actually let you know why I chose to talk about a "human society for the world," what is "smart and sustainable," why I used "rebuild" and not just "build."

You will build the conclusion. Yes, you! Because you and especially you + you..++ you + me are the only ones who can have an impact. And it is very likely that this article ends in "What can YOU do NOW to rebuild a smart and sustainable society for the world?"... but who knows, let's not spoil the end yet!

\section{METHODOLOGY}

A bit over 50 years ago, engineers brought human beings to the Moon: An incredible technological and project management success, a journey which had another unplanned result. In one step of this journey, Apollo 8 took human beings around the Moon for the first time, and its crew took this very famous picture of the Earth from the Moon called Earthrise.

This helped many realize that this planet, which seems so huge to us, the Earth, is like a very little spaceship in the huge cold universe.

And this is where I started from when I coordinated the work on the architecture of the Sulitest (United Nations, 2020). I'll tell you more about it in the Results section, but here, in "Methodology," I want to share with you what we'll do together:

1. Stand on the Moon, or in this Apollo 8 spacecraft, and look at planet Earth. 
2. We'll zoom in together and see the first thing from above: its life ecosystem called the biosphere... If we zoom in a bit more, we'll notice humanity and wonder how sustainable all of this currently is (yes, we will define "sustainable").

3. Zooming in a bit more, we'll explore people's needs, and the global and local humanconstructed systems to answer people's needs... By then, we will have noticed that those systems cannot continue "business as usual," or they might "cut the branch they are sitting on."

4. Continuing our zoom forward, we'll look at all the transitions towards sustainability, and that's where we'll bring in a very helpful concept, the Framework for Strategic Sustainable Development (FSSD), and a person, Ray Anderson.

5. I guess that by now you know where our zooming in will stop: you, me, them, all of us, the individuals, and the realization that we all have roles to play to create and maintain individual and systemic changes. A little dance on a hill, a bit of systems thinking, and hopefully you'll bring a few things from this journey.

By then I will probably end up asking a concluding question which launches a new journey: "What can YOU do NOW to rebuild a smart and sustainable society for the world?"

\section{RESULTS}

Let's start in December 1968 at John F. Kennedy Space Center, known as Cape Canaveral, in Florida, on the North American continent, when Apollo 8 is ready to be launched. It will take people around the Moon for the first time and bring them back. In their way back, they'll zoom in on us on Earth, most likely impacting a lot the three individuals in the spacecraft; in fact, impacting many more people, including this photo they took.

Let's fast-forward 50 years and a bit. Today's world is complex, interconnected and in perpetual transformation. Even small decisions can impact our global society. I'm writing this in October 2020. For the last eight to ten months, the whole world is aware that a very small thing like a virus can upset our huge and complex human system, with all its science and technology, and knowledge and beliefs.

The question that Sulitest (Sulitest, n. d.) started is even more relevant now: "How do we elevate awareness of key global challenges worldwide and support individuals, political and economic leaders, and all decision-makers in integrating an understanding of these systemic concerns in their daily practices?

Sulitest, for Sustainability Literacy Test, is a movement whose mission is to support expanded sustainability knowledge, skills and mindset that motivate individuals to become deeply committed to building a sustainable future, and to make informed and effective decisions. 
So, like the astronauts, and following the Sulitest's architecture, let's look at the Earth from the Moon and zoom in more and more until we reach you and me, individual human beings.

\subsection{Sustainable Humanity and Ecosystems on Planet Earth}

Our ecosystem, the biosphere: that's where all of life as we know it is, a few kilometers above and below sea level. If the Earth were a peach, this layer would be as thin as its skin.

Here is a story I read in a fantastic book by Ray Anderson called Mid-Course Correction (a title from an Apollo story too) (Anderson, 1998). Imagine we are on Saturday midnight, and the Earth started its creation on Monday morning (in real life, this is 4.5 billion years). The first cell arrived and survived on Tuesday morning around $8 \mathrm{a} . \mathrm{m}$. (we can start talking of life on Earth). Until Saturday at 23:53 p. m., seven minutes before midnight, the biosphere evolved to create the conditions for our ancestor, the Australopithecus, to arrive. About six seconds before midnight, it was our turn: the homo sapiens sapiens. And about 1/200 of a second before midnight, we learnt to split the atom. Some call this period "the Anthropocene," a proposed new era when human actions have a drastic effect on the Earth (Anthropocene, July 3 rd, 2021).

About 7.7 billion human beings currently live in this biosphere. Unfortunately, some have forgotten that they are part of it, and believe they are separated from something called "nature," in which we can throw things away (scroll up, look at the picture again and try to answer this question: "Where is away?!").

In 1987, a UN commission called the Brundtland Commission popularized and defined the term "sustainable development" in their report called "Our Common Future" (World Commission on Environment and Development, 1987): "development that meets the needs of the present without compromising the ability of future generations to meet their own needs." In my terms and adding a concept that came just after in the report: "we human beings can live well, now and everywhere, and will be able to continue to do so in the future." The scientific definition of sustainability I consider most useful to try to change this system is the one you can find in the Framework for Strategic Sustainable Development with its sustainability principles (Göran \& Karl-Henrik, 2017).

Current indicators show that our human society is not sustainable now. It means we need to change-and change fast-if we listen to indicators like the planetary boundaries (Steffen et al. , 2015); the ecological footprint and its Earth Overshoot Day (Global Footprint Network, n. d.); what we can see with migrations, health and hunger issues; and all those issues the Sustainable Development Goals (United Nations, n. d.) aim to address.

If we are smart enough, we will change fast enough. Using the metaphor in the FSSD, our society is already hitting some of the funnel's walls, but we can still change and reach 
sustainability at the end of the funnel and transform our human-constructed system and re-open the funnel's walls.

This would be SMART!

\subsection{Global and Local Human-Constructed Systems to Answer People’s Needs}

Over the last thousands of years, our human society has created many different ways to answer people's needs. Chilean economist Manfred Max-Neef has this very useful approach to plan changes in our complex system, where all human beings always and forever have the same fundamental human needs: subsistence, protection, affection, understanding, participation, idleness, creation, identity and freedom. Such changes consist in how we individually and collectively organize to answer those needs in a sustainable way or not (Max-Neef, Elizalde \& Hopenhayn, 1991).

Can we continue answering our need for energy when oil is causing both wars and climate change to get it? How could we produce food in a way that both feeds the planet and helps the biosphere? What local, national and global governances respect everybody's fundamental human needs? What is the role and impact of education in all of this, both in families and villages, and in schools and universities?

There are a lot of good news to answer those questions, and a lot of scary stories and facts too. I guess you have noticed by now that we can't simply continue "business-as-usual." But you might also have noticed that we (human beings) are "cutting the branch we are sitting on": the good news here is that we could control and stop it... if we hurry!

\subsection{Transitions Towards Sustainability}

So, let's "rebuild a human society for the world" or, as more often called, "transition towards sustainability."

Understanding how change happens is a whole big subject and so much needed if you want to be efficient for the desired change. A colleague and I spent five months studying the subject on how to engage individuals to act strategically towards sustainability (Richard \& Lundholm, 2005). Using the metaphor of the four elements, we discovered it was key to know who you are and what you want to achieve (earth), to understand others and the influence of the context (water), to know how change happens (air), to be able to build a coherent approach to this change (fire) and, of course, to manage those four elements with the fifth: systems thinking. We were very influenced by the work of Ray Anderson, the founder and CEO of the multinational carpet tile company called Interface. He and his company make up one of the initiatives showing how to change towards sustainability, proving it's both possible and profitable... and fun too. Have a look at his incredible TED talk (Anderson, 2009) on the business logic of sustainability and his fun (and bright!) use of the Ehrlich's equation: I (impact) $=\mathrm{Px}$ 
A x T (Population, Affluence and Technology). After suggesting the transformation of T into T2, a new technology, that could go in the denominator to reduce impacts. Here is what he says about A - Affluence:

And what if we made A a lowercase 'a, suggesting that it is a means to an end, and that end is happinessmore happiness with less stuff. You know that would reframe civilization itself and our whole system of economics, if not for our species, then perhaps for the one that succeeds us: the sustainable species, living on a finite earth, ethically, happily and ecologically in balance with nature and all her natural systems for a thousand generations, or 10,000 generations-that is to say, into the indefinite future. But does the earth have to wait for our extinction as a species? Well maybe so. But I don't think so.

The Framework for Strategic Sustainable Development, also known as The Natural Step Framework, is the best approach I've found to help create needed systemic and strategic changes. It is part of the DNA of Interface's work, and I've experienced many times how it can help people, from a factory worker to the head of a small business or to the CSR director of a big organization, and feel "ah-ah... this is a great way of making sense of it all."

\subsection{We Each Have Roles to Play, Create and Maintain Individual \& Systemic Changes}

And those "ah-ah moments" might be the most important ones. Some say, "it only takes a fraction of a second to change paradigm, it's the time it takes to get to this specific moment that can be long."

I learnt that the tipping point (when suddenly all behaviors shift) is when about $15 \%$ of a crowd takes on the new habit; then, suddenly, the majority adopts the new behavior. In this fabulous video, you can "watch a movement happen, start to finish, in under three minutes and dissect some lessons from it” (Sivers, 2010).

After all, every group and organization consist of several individuals coming together to do something. And that's the whole point: What can each person do with his or her own capacities and roles to accelerate change towards sustainability: "What can YOU do NOW to rebuild a smart and sustainable society for the world?"

\section{CONCLUSION}

You will build the conclusion. Yes, you! Because you and especially you +you+... you + me are the only ones who can have an impact.

Hopefully, your journey so far and the one to come will help our common and global journey. Helping to accelerate change towards sustainability is about creativity, collaboration, fun, innovation, being aware of the others, helping others, helping oneself, learning, discovering, doing, having an impact. Personally, I find it great. 
And I'll borrow my final words from an Australian colleague who had this as an email signature for a while (thanks Scotty):

If not now, when?

If not here, where?

If not you and I, who?

\section{REFERENCES}

Anderson, R. (1998). Mid-Course Correction. Chelsea Green Publishing.

Anderson, R. (2009). The business logic of sustainability [Archivo de Video]. TED. https:// www.ted.com/talks/ray_anderson_on_the_business_logic_of_sustainability

Anthropocene. (July 3rd, 2021). In Wikipedia. https://en.wikipedia.org/wiki/Anthropocene

Global Footprint Network (n. d.). Earth Overshoot Day https://www.footprintnetwork.org/ our-work/earth-overshoot-day/

Göran, B. \& Karl-Henrik, R. (2017). A framework for strategic sustainable development. Journal of Cleaner Production, 140,17-31.

Max-Neef, M. A., Elizalde A., \& Hopenhayn, M. (1991). Human Scale Development. http:// www.wtf.tw/ref/max-neef.pdf

Richard, R. \& Lundholm K. (2005). Engaging individuals to act strategically towards sustainability. Master's thesis, MSLS, BTH. http://www.diva-portal.org/smash/get/ diva2:830651/FULLTEXT01.pdf

Sivers, D. (2010). How to start a movement [Archivo de Video]. TED. https://www.ted.com/ talks/derek_sivers_how_to_start_a_movement

Steffen et al. (2015). Planetary Boundaries: Guiding human development on a changing planet. Science, 347(6223).

Sulitest. (n. d.) https://www.sulitest.org

United Nations. (n. d.). The 17 Goals. https://sdgs.un.org/goals

United Nations. (2020). Raising \& Mapping Awareness of the Global Goals High Level Political Forum on Sustainable Development. https://www.sulitest.org/files/source/ hlpf2020_report.pdf

World Commission on Environment and Development. (1987). Our Common Future.Oxford University Press. 